\title{
Éditorial
}

\section{La rédaction}

\section{(2) OpenEdition}

\section{Journals}

Édition électronique

URL : http://journals.openedition.org/travailemploi/9029

DOI : 10.4000/travailemploi.9029

ISSN : 1775-416X

Éditeur

DARES - Ministère du Travail

\section{Édition imprimée}

Date de publication : 2 octobre 2019

Pagination : 5-5

ISSN : 0224-4365

\section{Référence électronique}

La rédaction, « Éditorial », Travail et Emploi [En ligne], 158 | 2019, mis en ligne le 01 novembre 2019, consulté le 07 décembre 2020. URL : http://journals.openedition.org/travailemploi/9029 ; DOI : https://doi.org/10.4000/travailemploi.9029

Ce document a été généré automatiquement le 7 décembre 2020.

(c) Direction de l'animation de la recherche, des études et des statistiques (Dares) 
Éditorial

La rédaction 
1 La revue Travail et Emploi a 40 ans ! Créée en 1979 par le ministère du Travail, elle n'a cessé depuis cette date d'être tout à la fois un réceptacle d'idées, un lieu de débats et un vecteur d'analyses des profondes mutations qu'ont connues le travail et l'emploi au cours de ces quatre décennies. Éditée par la Direction de l'animation de la recherche, des études et des statistiques (Dares), elle est aujourd'hui une revue académique reconnue en sciences sociales, au sein et au-delà du champ du travail et de l'emploi. Souhaitant la diffusion la plus large possible des articles qu'elle publie, elle est désormais en accès libre sur Internet.

2 Si Travail et Emploi a atteint l'âge de la maturité, c'est bien évidemment grâce aux auteurs et autrices qui lui font confiance pour publier leurs travaux ainsi qu'aux lecteurs et lectrices qui manifestent leur intérêt pour ces derniers. Que l'on nous permette, à l'occasion de cet anniversaire, de mentionner également toutes celles et tous ceux qui ont fait vivre la revue, au quotidien, durant ces quatre décennies : les secrétaires de rédaction, les membres des comités de rédaction successifs, les rapporteurs et rapportrices, et les directeurs et directrices de publication qui l'ont toujours accompagnée et soutenue. En fonction aujourd'hui, maillons d'une histoire dont nous sommes les héritiers et les héritières, nous tenons ici à leur rendre l'hommage qu'elles et ils méritent.

3 Nous fêtons cet anniversaire avec ce numéro spécial et le colloque organisé le 10 décembre 2019 à Paris, rassemblant des acteurs et actrices de la revue, d'hier et d'aujourd'hui. Cet anniversaire est l'occasion de revenir sur les problématiques, les thèmes, les méthodes et les outils d'analyse qui ont marqué le travail et l'emploi depuis quarante ans, sur la place et le rôle de Travail et Emploi dans cette histoire ; c'est aussi l'occasion de tracer des perspectives pour les années à venir. Les auteurs et autrices des articles de ce numéro se sont prêtées à cet exercice. Elles et ils sont sociologues, économistes, historienne ou encore juriste et vous livrent ici leurs analyses, avec des regards pluriels, signe de l'interdisciplinarité qui caractérise la revue.

Bonne lecture de ce numéro qui ouvre une nouvelle décennie de Travail et Emploi ! 